\title{
Isotopic estimation of milk intake in sucking lambs with deuterium oxide space: effects of milk concentration and level of milk intake
}

\author{
F Bocquier, M Thériez, JP Brun \\ INRA, Laboratoire de la Lactation et de l'Elevage des Ruminants, \\ Theix, 63122 Saint-Genè-Champanelle, France
}

(Received 15 January 1991; accepted 6 June 1991)

\begin{abstract}
Summary - Twenty-three artificially-reared lambs were injected at 23 and $35 \mathrm{~d}$ after birth with deuterium oxide $\left(\mathrm{D}_{2} \mathrm{O}\right)$ used as a marker of body water. During both periods they were divided into 3 experimental groups. During the first period they received milk replacers ad libitum at different dry matter (DM) concentrations: $13.5,15.7$ or $17.7 \%(w / w)$. During the second period, milk was supplied at 3 levels of intake: $7.8,8.7$ and $9.6 \%$ of live-weight. Suggestions put forward by different authors to take into account non-steady states of water pool content in growing animals were confirmed as adequate. Under both diet conditions, the $\mathrm{D}_{2} \mathrm{O}$ dilution technique was found to be efficient for prediction of total water intake of milk-fed lambs $\left(R^{2}=0.975 ; \mathrm{RSD}= \pm 36 \mathrm{~g} / \mathrm{d}\right)$. A brief survey of milk yield and milk DM content variations observed in nutritional trials with suckling ewes showed that milk yields were far more affected by experimental treatments than by milk DM variations. In this case, choice of a mean DM content is acceptable for the calculation of metabolic water contribution. The use of deuterium oxide as a non-radioactive marker with minimal handling procedure appears useful for estimation of milk yield in suckling ewes. It can also be used to simultaneously estimate the body composition of lambs.
\end{abstract}

ewe / milk yield / lamb / marker

Résumé - Estimation de la quantité de lalt consommée par les agneaux avec la méthode de l'espace de diffusion de l'eau lourde $\left(\mathrm{D}_{2} \mathrm{O}\right)$ : effets de la concentration et de la disponibllité en lait. L'eau lourde $\left(\mathrm{D}_{2} \mathrm{O}\right)$, utilisée comme marqueur de l'eau corporelle, a été injectée à 23 agneaux en allaitement artificiel répartis en 3 groupes expérimentaux dont on a mesuré les consommations. En première période (23 $j$ après la naissance), ils étaient ad libitum et recevaient des laits de différentes concentrations : 13,5, 15,7 ou 17,7\% de MS. En seconde période (+ 35 j) 3 niveaux d'apports en lait ont été imposés : 7,8, 8,7 et 9,6\% du poids vif. L'espace de diffusion de l'eau lourde ainsi que le taux de renouvellement de l'eau corporelle ont été calculés d'après les teneurs sanguines en $\mathrm{D}_{2} \mathrm{O}$ mesurées pendant 4 jours.

Il existe une relation étroite entre le taux de renouvellement de l'eau corporelle et l'eau bue par les agneaux. Les corrections proposées pour tenir compte de l'accroissement du volume hydrique pendant la mesure (4 $j)$ se sont avérées efficaces pour prévoir l'eau bue $\left(\mathrm{R}^{2}=0.975 ; R S D= \pm 36 \mathrm{~g} / \mathrm{j}\right)$. La méthode est fiable quels que soient les concentrations en MS du lait (ns) et les niveaux de consommation (ns). L'estimation de l'eau métabolique, provenant de la transformation des nutriments, repose sur des hypothèses qui sont discutées. Les résultats de la bibliographie montrent que le choix d'une teneur moyenne en MS du lait de brebis entraîne des erreurs minimes dans l'estimation 
du lait bu. Cette méthode est donc précise et fiable pour estimer les consommations de lait par les agneaux pendant l'allaitement. De plus, elle permet d'estimer simultanément la composition corpo. relle des agneaux.

brebls / production laitière / agneau / marqueur

\section{INTRODUCTION}

It is of particular importance to find reliable methods for the estimation of milk intake by lambs, either for explanation of differences in lamb growth rates or for analysis of the effects of nutrition on the distribution of available nutrients between milk output and other requirements (body reserves and/or wool growth) in the ewe. Available methods (Doney et al, 1979) should be adapted to the design of the experiment in respect of required accuracy. General relationships between lamb growth rate and milk intake (Ricordeau et al, 1960) are of poor precision in nutrition experiments. Milking procedures must be applied carefully and results should be viewed with caution, mainly because suckled ewes are not accustomed to milking (machine or manual) and use of exogenous oxytocin affects both volume and milk composition. The test-weighing method is debatable in sheep unaccustomed to frequent handling.

Under these conditions, methods based on single tracer injection to determine body-water turnover in normally-sucking lambs might be an adapted solution. However, these techniques should be used only for a limited period when milk is the sole source of water and/or when water intake is controlled. This limitation is not serious since ewe peak milk yields appear around 3rd wk of lactation when lamb water intake is nil or low. On the other hand, the main advantage of this technique is that the degree of udder emptying only depends on lamb activity which might not be changed with limited handling procedures.
Body-water dilution techniques are based on the use of water isotopes; tritiated water (TOH: MacFarlane et al, 1969; Dove and Freer, 1979) or deuterium oxide $\left(\mathrm{D}_{2} \mathrm{O}\right.$; in foal: Doreau and Dussap, 1980; and in piglets: Pettigrew et al, 1987). Deuterium oxide was seldom used due to its cost and difficulty of estimation in blood, but this is no longer the case (Tissier et al, 1978; Byers, 1979) and the use of nonradioactive tracer is of substantial advantage compared to $\mathrm{TOH}$ when applied to farm animals. We did not follow the procedure used by Dove (1988) using a double isotope dilution technique, TOH in ewe, $\mathrm{D}_{2} \mathrm{O}$ in lambs, because this method was shown to be adequate when milk is not the major source of water.

The first aim of this experiment was to predict milk intake of lambs with a specific equation using $\mathrm{D}_{2} \mathrm{O}$ as a marker. The second objective was to measure the practical consequences of differences in milk concentration and to third was to assess the practical use of this method in conditions of limited milk supply.

\section{MATERIALS AND METHODS}

\section{Animals and experimental diets}

Twenty-three lambs, pure Limousine (11) or Limousine crossed (12) were individually penned indoors and artificially fed from lambing with a milk replacer. Lambs were twice infused with $\mathrm{D}_{2} \mathrm{O}$ at $\mathrm{d} 23$ and 35 after birth (see below).

During the first period, lambs were offered the same milk replacer ad libitum (15\% refusals) 
at $3 \mathrm{DM}(w / w)$ concentrations: $13.5(n=8$ lambs), $15.7(n=7)$ and $17.7 \%(n=8)$ to assess the effect of variability in nutrient concentration of ewes' milk on estimation of milk intake.

After completion of the first period, the DM of milk replacer was standardized $(16.0 \% \mathrm{w} / \mathrm{w})$ and milk availability was progressively reduced to simulate the observed decline in milk yield (Bocquier et al, 1987). During the second period the same lambs were offered 1 of the 3 levels of milk replacer at: $7.82(n=8), 8.74(n=8)$ and $9.62 \%(n=7)$ of bodyweight per $d$ and had free access to drinking water and concentrate.

At both periods milk was given in 2 equal meals (09.00 and $13.00 \mathrm{~h}$ ).

\section{Measurements and analysis}

\section{Milk intake and liveweight}

Intake was measured daily and samples of offered and refused milk were taken for DM determination $\left(48 \mathrm{~h}\right.$ at $80^{\circ} \mathrm{C}$ ). Commercial milk powder was composed of $27 \%$ crude protein, $38 \%$ lactose, $25 \%$ fat and $10 \%$ ash in DM. Concentrate and water intake were also measured daily in the second period. Lambs were weighed weekly $(13.00 \mathrm{~h})$ during the entire experiment and daily during marker collections.

\section{Dilution procedure}

Lambs were infused with $\mathrm{D}_{2} \mathrm{O}\left(1 \mathrm{~g} \mathrm{D}_{2} \mathrm{O} / \mathrm{kg} \mathrm{BW}\right)$ with a catheter inserted in the jugular vein. Injected $\mathrm{D}_{2} \mathrm{O}$ was measured by difference between pre- and post infusion weight of syringes (nearest $\mathrm{mg}$ ). For both periods, lambs were injected at $09.00 \mathrm{~h}$ and blood samples were taken (by venipuncture) at $13.00 \mathrm{~h}$, on the day of infusion and at $13.00 \mathrm{~h}$ during the following 3 days. Concentrations of $\mathrm{D}_{2} \mathrm{O}$ were determined by infrared spectrophotometry after water extraction by vacuum sublimation (Tissier et al, 1978). Water space diffusion ( $S P A C E, \mathrm{~g})$ was calculated by back extrapolation after $\log _{N}$ transformation of blood concentrations of $\mathrm{D}_{2} \mathrm{O}$ (Robelin, 1983). Apparent water turnover rate (TURNapp, g/d) was determined by multiplying fractional turnover rate (ie slope) with space:

$$
\text { TURNapp }=\text { Slope } \times \text { SPACE }
$$

The knowiedge of $\mathrm{D}_{2} \mathrm{O}$ diffusion space also allowed the calculation (Robelin, 1977) of body composition of each lamb.

Estimation of metabolic water formation from solid milk nutrients was calculated from digestibility trials (Villette and Theriez, 1983). With the same type of milk replacer the digestibility coefficients were 0.96 for fat, 0.97 for protein and 0.99 for lactose. We assumed catabolism to be the difference between body chemical deposits (Robelin, 1977) and metabolizable nutrient intake. These hypotheses led to a conversion factor $(\mathrm{Cm})$ of $0.45 \mathrm{~g}$ metabolic water per $\mathrm{g}$ milk OM.

To convert the measured total water intake (TW/, g/d) into milk yield ( $M Y, g / d)$, dry matter content (DMm, \%) of milk should be known and other water sources substracted, ie liquid water intake and water from solid food intake (SFI):

$T W I=$ Water from milk + other sources

ie : Water from milk $=(1-D M m) \times M Y$ + Metabolic water related to milk $D M m$ intake: $D M m \times C m \times M Y$

+ Water intake (if any)

+ Water from solid food: $(1-D M S) \times S F I$

+ Metabolic water from solid food related to nutrient intake: $D M s \times S F I \times C s$

In the first period, the main water supply was milk:

$$
\text { ie } \begin{aligned}
T W I & =M Y \times((1-D M m)+D M m \times C m) \\
M Y & =T W I /(1-(D M m \times(1-C m)))
\end{aligned}
$$

Data were analyzed by linear regression and by analysis of variance and covariance.

\section{RESULTS}

\section{Lamb growth}

Mean bodyweights of lambs were respectively 5.6 and $12.0 \mathrm{~kg}$ at the first and second infusions with an average daily gain (ADG) of 283 and $186 \mathrm{~g} / \mathrm{d}$ (tables I and II). During the ad libitum period milk intakes were very variable either between lambs 
Table I. Mean characteristics of lambs during the first part of experiment. Effect of milk DM content.

\begin{tabular}{|c|c|c|c|c|}
\hline \multirow[t]{2}{*}{ Milk replacer } & \multicolumn{3}{|c|}{ DM content (\%) } & \multirow{2}{*}{$\begin{array}{l}\text { Overal } \\
S D(1)\end{array}$} \\
\hline & 13.5 & 15.7 & 17.7 & \\
\hline \multicolumn{5}{|l|}{ Intake $(g / d)$} \\
\hline Milk intake & 2007 & 1784 & 1807 & 454 \\
\hline Milk DM intake & 276 & 282 & 315 & 69 \\
\hline Total water intake & 1918 & 1629 & 1634 & 420 \\
\hline \multicolumn{5}{|l|}{ Lamb liveweight ( $\mathrm{kg}$ ) } \\
\hline At birth & 4.29 & 4.49 & 4.39 & 0.70 \\
\hline At injection $\quad$ (BWO) & 5.38 & 5.72 & 5.88 & 0.91 \\
\hline Injection + $4 d(B W 4)$ & 6.49 & 6.87 & 7.12 & 1.00 \\
\hline \multicolumn{5}{|l|}{ Chemical composition (kg) } \\
\hline Body water & 4.19 & 4.54 & 4.64 & 0.66 \\
\hline Body lipid & 0.33 & 0.34 & 0.37 & 0.08 \\
\hline Body protein & 0.82 & 0.87 & 0.89 & 0.14 \\
\hline Body energy (MJ) & 30.7 & 32.1 & 33.4 & 6.27 \\
\hline
\end{tabular}

(1) None of these differences were significant $(P>0.05)$.

$(615-2860 \mathrm{~g} / \mathrm{d})$ or from day to day. During the restricted period milk intake was limited and ADG were reduced. On both periods, infusion of $\approx 5-12 \mathrm{~g} \mathrm{D}_{2} \mathrm{O}$ per lamb caused little disturbance (only 5 of over 46 injected lambs had reduced ADG following infusion).

\section{Relationship between milk intake and lamb growth}

During the first part of the experiment, the relationship between total milk intake and ADG was poor $\left(R^{2}=0.43, P<0.01\right)$ with a residual standard deviation of $\pm 383 \mathrm{~g} / \mathrm{d}$ $(\mathrm{CV}=18.4 \%$, fig 1$)$. This was due to difference in milk DM content $(P<0.01)$, water intake increased as DM content decreased and lamb growth rate was better related to milk DM intake $\left(R^{2}=0.75, P<0.001 ; \mathrm{CV}=\right.$ $12.2 \%$ ). During the restricted period, lamb

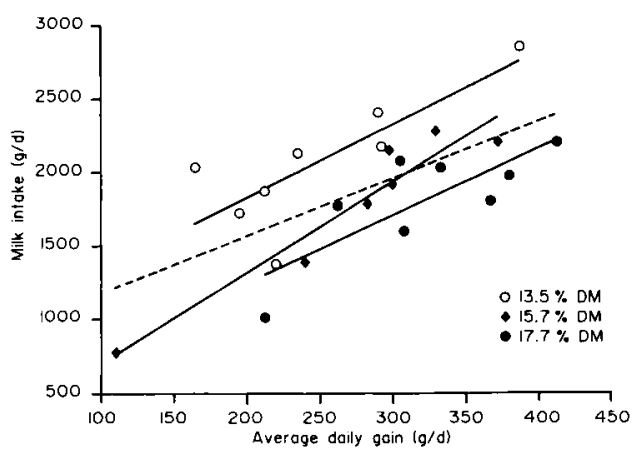

Fig 1. Relationship between lamb weight gain and milk intake: effect of milk dry matter concentration. 
Table II. Mean characteristics of lambs during the second part of experiment: Effect of milk restriction.

\begin{tabular}{|c|c|c|c|c|}
\hline Milk replacer & $\begin{array}{c}\text { Milk } \\
\text { Low } \\
(78.2)\end{array}$ & $\begin{array}{l}\text { ailability ( } g \\
\text { Medium } \\
\text { (87.3) }\end{array}$ & $\begin{array}{l}g / d) \\
\text { High } \\
(96.2)\end{array}$ & $\begin{array}{l}\text { Overall } \\
S D(1)\end{array}$ \\
\hline \multicolumn{5}{|l|}{ Intake $(g / d)$} \\
\hline Milk intake & 945 & 1091 & 1115 & 180 \\
\hline Milk DM intake & 137 & 158 & 162 & 26 \\
\hline Concentrate DM & 69 & 59 & 34 & 36 \\
\hline Fresh water intake & 7 & 6 & 7 & 4 \\
\hline Total water intake & 857 & 977 & 961 & 155 \\
\hline \multicolumn{5}{|l|}{ Lamb liveweight $(\mathrm{kg})$} \\
\hline At injection (BWO) & 11.6 & 11.6 & 10.9 & 1.87 \\
\hline Inject + $4 \mathrm{~d}$ (BW4) & 12.6 & 13.0 & 12.2 & 1.98 \\
\hline \multicolumn{5}{|c|}{ Chemical composition (kg) } \\
\hline Body water & 8.46 & 8.68 & 8.11 & 1.28 \\
\hline Body lipid & 1.20 & 1.25 & 1.20 & 0.33 \\
\hline Body protein & 1.86 & 1.91 & 2.81 & 0.32 \\
\hline Body energy (MJ) & 89.1 & 92.2 & 87.8 & 20.4 \\
\hline
\end{tabular}

(1) Nine of these differences were significant $(P>0.05)$.

growth was poorly (ns) related to milk intake. The concentrate intake was low $(53 \mathrm{~g}$ $\mathrm{DM} / \mathrm{d}$, ie $8 \mathrm{~g}$ of water) as was water intake (7.5 g/d, table II). Under our conditions, water supply from milk replacer was the most important $(720 \mathrm{~g} / \mathrm{d})$, compared to $15.5 \mathrm{~g} / \mathrm{d}$ from other sources.

\section{Estimation of milk intake}

A limitation of this method might be connected with the increase in body water pool (non-steady state) during the measurement period (4 d). This bias might lead to an overestimation of milk intake (Holleman and White, 1988) but appropriate corrections have been proposed by Dove and
Freer (1979) for lambs (formula (4)) and by Doreau and Dussap (1980) for foals. The Dove's correction had been applied to our data:

$$
\begin{aligned}
& \text { TURNcor }=\text { TURNapp } \times\left(\left(V_{4}-V_{0}\right) / V_{0}\right) / \\
& \left.\left(\operatorname{LogN}\left(V_{4} / V_{0}\right)\right)\right)
\end{aligned}
$$

where $V_{0}$ is initial body water and $V_{4}$ water volume after $4 \mathrm{~d}$. Assuming that the water volume $(V)$ to body weight $(B W)$ ratio was constant during measurement period we replaced $V_{i}$ by $B W_{i}$ in formula (4).

Corrected turnover was plotted against total water intake (ie milk water + metabolic water + water from other sources; see fig 2). Relationship of prediction of total water intake (TWI, g/d) was not different 


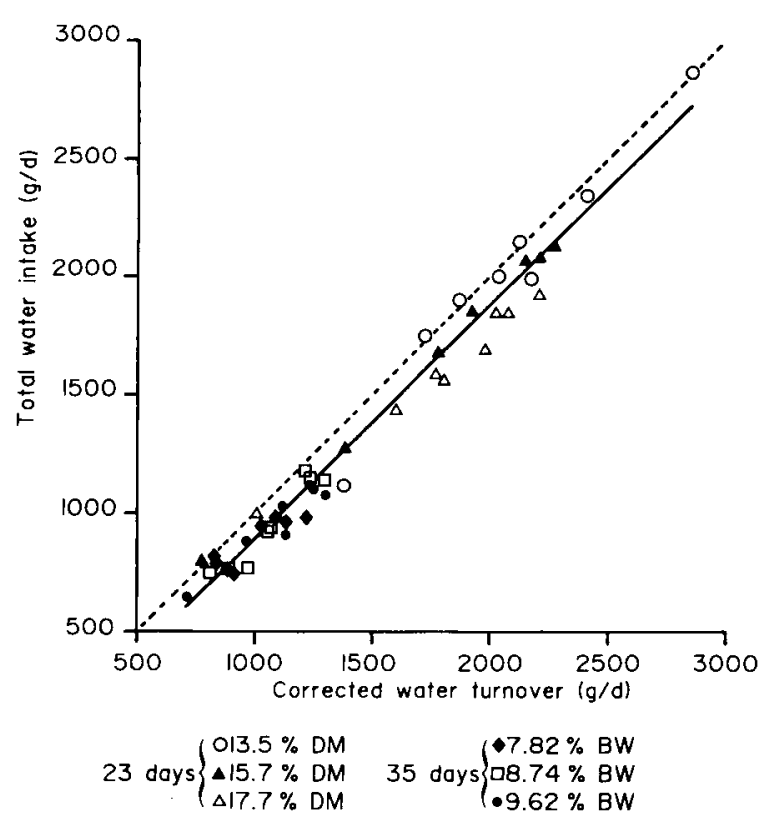

Fig 2. Relationship between corrected water turnover and total water intake of lambs.

on overall data between ad libitum (first period) and restricted period (second part) when tested by covariance analysis:

$$
\begin{aligned}
& T W I=0.987 \times \text { TURNCor }-97 \\
& \mathrm{~g} / \mathrm{d} \pm 0.023 \mathrm{~g} / \mathrm{d} \quad(R S D= \pm 36, n=46) \\
& \left(R^{2}=0.975, P<0.001\right)
\end{aligned}
$$

The estimated chemical body composition of lambs was not significantly (ns) affected by treatments within each period (tables I and II). No direct comparisons can be made between first and second period treatments since lambs were reallocated.

\section{DISCUSSION}

\section{Lamb growth and milk intake}

Lamb growth rates during the first period were within the observed range for this breed of sheep. During the second period reduced ADG were due to the restriction of milk availability and probably to a slow adaptation to concentrate. This might be due to isolation of lambs in individual pens. In normal conditions social facilitation might help the transition from liquid to solid food with no reduction of $A D G$. 
Many relationships between live-weight gain and ewe's milk yield have been reported in the literature; our results $(R=$ 0.65 ) are within the wide range of observed correlation coefficients, from $0-$ 0.91 (Ricordeau et al, 1960; Robinson et al, 1969; Torres-Hernandez and Hohenboken, 1980). Torres-Hernandez and Hohenboken (1980) found no direct effects of milk DM content on the relationship, but inclusion of protein content as a second variable increased the correlation coefficient from 0.73 to 0.86 . In our experiment, the relationship between $A D G$ and milk consumption was poor because, under ad libitum conditions, lambs partly adjusted their milk consumption to nutrient intake, so that when DM increased total milk intake decreased. This was confirmed by a better relationship observed between $D M$ intake and ADG $(R=0.86)$, as previously shown by Large (1965) and Molénat and Thériez (1974).

\section{Corrected turnover rate and water intake}

Mean correction of water turnover for increase in body water content was more important in the first period $(9.7 \%)$ than in the second $(2.6 \%)$. This is directly related to the ADG differences between periods; in the second period, water space variations due to non-steady state were small. These values are in agreement with those observed by Dove (1988) in early lactation. Even if this correction only slightly improves the prediction of water intake, it has been kept since it may be more general and might be necessary for higher ADG or for longer periods of measurements (Holleman and White, 1988). The small overestimation of body water turnover (constant term: $-97 \mathrm{~g} / \mathrm{d}(P<0.05)$, in equation (5) might be due to the well-known overestimation of total body water by water space diffusion (Robelin, 1977).

\section{Metabolic water and its estimation}

Estimation of metabolic water production using nutrient intake appears reliable because the slope between corrected turnover and total water intake is near 1 (0.987). The coefficient of conversion $(\mathrm{Cm}$ $=0.45$ ) is lower than that assumed by Dove and Freer (1979), but in good agreement with that proposed by Doreau and Dussap (1980) in foals using another method. Metabolic water from concentrate was neglected due to low intake. Milk DM content can be directly measured by milking techniques or assumed from the literature; the overall mean value of DM content of ewe milk is $189 \mathrm{~g} / \mathrm{kg}$ with a $\pm 4.0 \%$ range of variation (authors: mean \pm range $\%$; Cowan et al, 1980: $199 \pm 2.3 \%$; Cowan et al, 1981: $210 \pm 5.5 \%$; Geenty and Sykes, 1986 a,b: $182 \pm 3.8 \% ; 171 \pm 5.8 \%$ and $183 \pm 2.7 \%$ ). The consequence of DM variation within the observed range $(4 \%)$ lead to 25 to $30 \mathrm{~g} / \mathrm{ewe} / \mathrm{d}$ bias on milk yield (ie $1 \%$ ). Compared to the direct effects of feeding treatments on milk yield in those nutritional trials (Cowan et al, 1980: $900 \mathrm{~g}$ / d; Cowan et al, 1981: 982 g/d; Geenty and Sykes, 1986 a,b: $490 \mathrm{~g} / \mathrm{d}, 742$ and $166 \mathrm{~g} /$ d), the effects of unknown milk DM variations. on milk yield estimations are far below induced milk yield variations.

\section{Corrected turnover rate and milk yield}

From milk water intake of lamb, estimation of the actual ewe's milk yield can be calcu- 
lated with little bias assuming $D m=0.189$ and $C m=0.45$ from equation 3:

Milk yield $=1.116 \times(T W I-$ other water sources)

Water turnover measurements in sucked lambs using the procedure described here cause little disturbance to the lambs: a double weighing; at injection and at last sampling, with a limited number of blood samples. This technique improves the accuracy with which milk intake may be predicted from other methods; namely test-weighing or oxytocin milking techniques. Test-weighing is presumed to estimate the milk consumption by the lamb(s) while the oxytocin measures the rate of milk secretion by the ewe (Doney et al, 1979). During test-weighing measurements, particularly in early lactation, lamb milk intake is reduced by animal disturbances; probably due to lamb-ewe isolation and inadequate suckling frequency. With the oxytocin procedure, responsiveness to oxytocin injection before milking is very variable between ewes, and milking interval has a strong effect on milk secretion rate (unpublished observations). Comparisons reported by Doney et al (1979) revealed that oxytocin gave an overestimate of $13-23 \%$ when compared to test-weighing. When milk is the only source of water (or if extra milk water is controlled), the dilution technique seems to be the best method ensuring that milk rate secretion of the ewe and milk extraction by lambs are equal.

\section{CONCLUSION}

Reliable estimates of milk output are needed to calculate nutrient balances in ewe or lambs. This method can be applied sever- a) times consecutively to the same lamb with a preinfusion $\mathrm{D}_{2} \mathrm{O}$ concentration subtracted. Deuterium oxide, as a stable isotope, could be preferred to $\mathrm{TOH}$ which is radioactive with biological hazard, together with the major advantage that it does not disrupt normal maternal-offspring relationship during measurements. We confirmed here the suitability of this method in both cases of DM content variation and reduced milk availability. Meanwhile, this method is better adapted for indoor experiments (winter) than for grazing trials (see Dove, 1988).

\section{ACKNOWLEDGMENTS}

We greatly appreciate the work of $V$ Chatelain in her final course of INA-PG studies and H Cassagnes for animal care.

\section{REFERENCES}

Bocquier $F$, Thériez $M$, Brelurut A (1987) Recommandations alimentaires pour les brebis en lactation. Bull Tech CRZV, INRA, Theix, 70, 199-211

Byers FM (1979) Extraction and measurement of deuterium oxide at tracer level in biological fluids. Ann Biochem 98, 208-213

Cowan RT, Robinson JJ, McDonald I, Smart R (1980) Effect of body fatness at lambing and diet in lactation on body tissue loss, feed intake and milk yield of ewe in early lactation. J Agric Sci (Camb) 95, 497-514

Cowan RT, Robinson JJ, McHattie I, Pennie K (1981) Effect of protein concentration in the diet on milk yield, changes in body composition and the energy utilization of body tissue for milk production in ewes. Anim Prod 33, 111-120

Doney JM, Peart JN, Smith WF (1979) A consideration of the techniques for estimation of milk yield by suckled sheep and a comparison of estimates obtained by two methods in 
relation to the effect of breed, level of production and stage of lactation. I Agric Sci (Camb) 92, 123-132

Doreau M, Dussap G (1980) Estimation de la production laitière de la jument allaitante par marquage de l'eau corporelle du poulain. Reprod Nutr Dev 20, 1883-1892

Dove H (1988) Estimation of the intake of milk by lambs, from turnover of deuterium- or tritium labelled water. Br J Nutr 60, 375-387

Dove H, Freer M (1979) The accuracy of tritiated water turnover rate as an estimate of milk intake in lambs. Aust $J$ Agric Res 30, 725739

Geenty KG, Sykes AR (1986a) A note on the estimation of milk production in sheep. Anim Prod 43, 171-174

Geenty KG, Sykes AR (1986b) Effects of herbage allowance during pregnancy and lactation on feed intake, milk production, body composition and energy utilization of ewes at pasture. J Agric Sci (Camb) 106, 351-367

Holleman DF, White RG (1988) Analytical procedure for estimation of milk intake and yield in steady-state and non steady state systems. J Dairy Sci 71, 1189-1197

Large RV (1965) The effect of concentration of milk substitute on performances of artificially reared lambs. Anim Prod 7, 325-332

MacFarlane WV, Howard B, Siebert BD (1969) Tritiated water in the measurement of milk intake and tissue growth of ruminants in the field. Nature (Lond) 221, 578-579

Molénat G, Thériez M (1974) L'allaitement artificiel des agneaux V. Comparaisons de diffé- rentes concentrations du lait de remplacement. Ann Zootech 23, 491-502

Pettigrew JE, Cornelius SG, Moser RL, Sower AF (1987) A refinement and evaluation of the isotope dilution method for estimating milk intake by piglets. Livest Prod Sci 16, 163-174

Ricordeau G, Boccard R, Denamur R, Petrequin $P(1960)$ Mesure de la production laitière des brebis pendant la période d'allaitement. Ann Zootech 9, 92-120

Robelin J (1977) Estimation in vivo de la composition corporelle des agneaux à partir de l'espace de diffusion de l'eau lourde. Ann Biol Anim Biochim Biophys 17, 95-105

Robelin J (1983) Prediction of body composition in vivo by dilution technique. In: In Vivo Measurement of Body Composition in Meat Animals (Lister D, ed) Elsevier, 106-112

Robinson JJ, Foster WH, Forbes TJ (1969) The estimation of the milk yield of a ewe from body weight data on the suckling lamb. $J \mathrm{Ag}$ ric Sci Camb 72, 103-107

Tissier M, Robelin J, Purroy A, Geay Y (1978) Extraction et dosage automatique rapide de l'eau lourde dans des liquides biologiques. Ann Biol Anim Biochim Biophys 18, 12231228

Torres-Hernandez G, Hohenboken W (1980) Relationships between ewe milk production and composition and preweaning lamb weight gain. J Anim Sci 50, 597-603

Villette $Y$, Thériez $M$ (1983) Quantités ingérées par des agneaux en allaitement maternel pendant la première semaine de vie. Ann Zootech 32, 427-440 